\title{
The More Things Change
}

\section{Tom Regan \\ North Carolina State University}

A review of Richard Ryder's

Animal Revolution: Changing Attitudes

Towards Speciesism (Oxford, England and

Cambridge, Massachusetts: Basil Blackwell

Ltd, 1989).

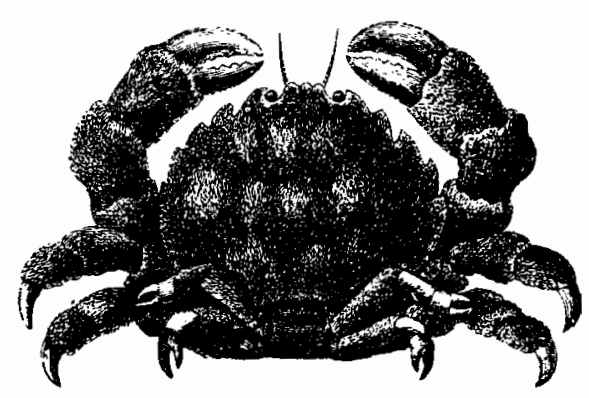

Among other notable accomplishments, Richard Ryder is a survivor. Whereas others have come and gone, or seen their star rise only to fall, Ryder has demonstrated true British grit. Today, after more than twenty years of activism on behalf of nonhuman animals, he is more not less committed, and his influence is larger not smaller. While this former young Turk, an original member of the Oxford Group, has become part of the animal welfare establishment (Ryder is past chairman of the Royal Society for the Prevention of Cruelty to Animals [RSPCA] and currently serves as its vice-chairman), he has not lost his fire or his vision. With the publication of his impressive historical work, Animal Revolution: Changing Attitudes Towards Speciesism, Ryder has consolidated his position as one of the world's most informed, articulate and politically astute voices being raised against those speciesist attitudes and practices that keep nonhuman animals in bondage.

Ryder's own career understandably is part of the history he tells. Though small in number, the members of the Oxford Group played-and many of them continue to play-a decisive role in the struggle for animal rights. In addition to Ryder, Andrew Linzey

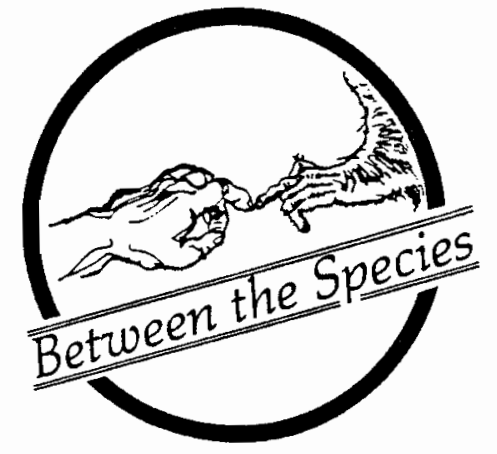

and Stephen Clark were part of the Group that was formed in Oxford in the late 1960s and early 1970s, as were three young Oxford philosophers: Roslind and Stanley Godlovitch, and John Harris, who, in 1971, with the publication of Animals, Men and Morals: An Inquiry into the Maltreatment of Non-humans (Gollancz), fired what many regard as the first volley in "the modern movement" for animal rights, a not altogether accurate characterization given the earlier, pioneering work of such figures as Helen Jones, for example.

Peter Singer, who knew the members of the Oxford Group but was not himself a member while a student in Oxford, fired the next volley when, in 1973, he published his seminal review of Animals, Men and Morals in the New York Review of Books. Here was a case where a review proved to be even more important than the important book that was reviewed. Singer's brief against animal exploitation was clear, concise and compelling, and reader response was overwhelmingly favorable-so favorable, in fact, that the New York Review of Books itself took the unusual step of actually publishing a book by Singer.

That book was Animal Liberation. The year was 1975, the same year Ryder published Victims of Science: The Use of Animals in Science (Davis-Poynter), "one of the central books of the animal liberation movement," in Brigid Brophy's words. A year later Andrew Linzey's Animal Rights: A Christian Assessment of Man's
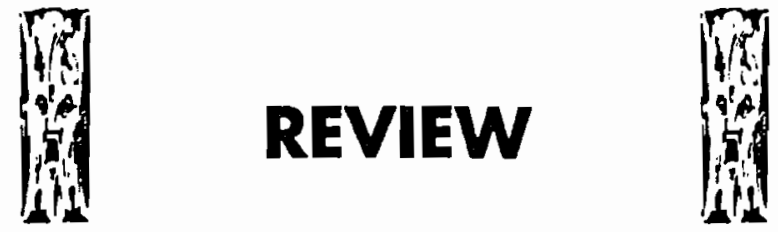
Treatment of Animals (SCM Press) was published, and a year after that saw Stephen Clark's The Moral Status of Animals (Oxford). By 1977, then, the modern movement was well launched, and the small band of progressive anti-speciesists who comprised the Oxford Group (Ryder had coined the term "speciesism" in 1970) played a historically decisive role in launching it.

Ryder's role has been more than theoretical. He has been, and continues to be, a man of action, and it was in no small measure because of his leadership that the RSPCA has experienced what many regard as a significant period of reform. Moreover, Ryder, along with Andrew Linzey, oversaw the organization of the historically important 1977 Cambridge Conference on Animal Rights, so-called because it was held at Trinity College, Cambridge University, the proceedings of which were later published as Animals' Rights: A Symposium (Centaur, 1979). Ryder drafted "A Declaration Against Speciesism" that was signed by 150 of the attendees. The Declaration reads as follows:

Inasmuch as we believe that there is ample evidence that many other species are capable of feeling, we condemn totally the infliction of suffering upon our brother and sister animals, and the curtailment of their enjoyment, unless it be necessary for their own individual benefit.

We do not accept that a difference in species alone (any more than a difference in race) can justify wanton exploitation or oppression in the name of science or sport, or for food, commercial profit or other human gain.

We believe in the evolutionary and moral kinship of all animals and we declare our belief that all sentient creatures have rights to life, liberty and the quest for happiness.

We call for the protection of these rights.

Of this declaration, Ryder notes that it was "youthful and idealistic in tone" (p. 197). Of the conference itself, he observes that it "was not only a novelty for the RSPCA, it was the first serious conference ever held anywhere, which was devoted entirely to animal rights, and I hope, the last such occasion at which meat was offered to those staying for lunch!" (p. 198). That hope, like the declaration, has proven to be "youthful and. idealistic." At a major international conference in 1990, organized by the RSPCA and held at Christ College,
Oxford, meat dishes, ranging from morning sausage and bacon to cuts of pork and beef, were offered at each of the meals. Only after enough of those in attendance raised their collective voice in opposition were veal and venison removed from the menu. The moral conscience of the majority was salved when chicken and salmon were substituted, while, like proverbial untouchables, vegans were asked to sit en masse at a table of their own.

The history of the modern movement, including the important contributions by members of the Oxford Group, is but one part of the large historical landscape Ryder presents, a landscape that traces the attitudes of humans to other animals from the cave paintings of Lascaux and Altamira up to, and beyond, the activities of the Animal Liberation Front. In between there are separate chapters on "The Christian Legacy: Medieval Attitudes" and "The International Movement, 17001960," for example. Without wishing to disparage Ryder's contributions to our understanding of these different times and nations, it remains true that his book is for the most part a history of British attitudes toward nonhuman animals, and it is as a contribution to the history of these attitudes that its real significance will be measured.

The British portrait, as drawn by Ryder, is not a pretty one. Even into the latter part of the eighteenth century people made sport of eating live cats at country fairs, and considerable ingenuity was shown in arranging bloody, fatal contests between animals. These and other blood sports, as well as bear, boar and bull baiting, found favor among the "lower" classes and in part helped form Continental perception of the British as coarse and cruel. Indeed, Ryder himself is moved to observe that "perhaps it was partly because Britain had been the cruelest nation in Europe that it led the humane reaction over the next two decades" (p. 64).

And lead they did, from the less well-known but visionary theology of Humphrey Primatt, whose 1776 book, The Duty of Mercy and the Sin of Cruelty to Brute Animals, still deserves to be read, to the better-known poets of compassion-Pope, Goldsmith, Burns, Blake, Coleridge, Wordsworth, Byron,, and Shelley, for example-and the philosophers Jeremy Bentham and John Stuart Mill, whose utilitarian enfranchisement of all sentient animals into the moral community continues to exercise its power and influence even today. The modern movement, it seems safe to say, would not be what it is if these creative pioneers had not paved the way. 
The history of the British struggle against speciesism is more than the emergence of new voices in theology, poetry, and philosophy. Part of this struggle has been waged in the trenches of parliament, and the story Ryder tells will not gladden the hearts of partisans of animal rights. Perhaps it is not surprising that the first animal protection bill introduced before parliament, which would have prohibited bull baiting, was defeated (this was in April of 1800), or that other proposed legislation also failed. Sadly, it was another twenty-two years before the first animal protection legislation, the famous Martin Act, was passed. But it is more than surprising, it is disconcerting to learn that the 1876 Cruelty to Animals Act actually afforded more protection to scientists using nonhuman animals in their research than it provided the animals themselves, and that it was more than another hundred years before that act was amended, with few gains, in the eyes of many critics, for the animals.

Still efforts were made, and like-minded people began to join in common cause so as to exert their collective power on behalf of animal protection. Under the leadership of Rev. Arthur Broome, the Society for the Prevention of Cruelty to Animals was launched on June 16, 1824; when, in 1840, Queen Victoria gave her blessing, this Society became the Royal Society for the Prevention of Cruelty to Animals and earned, by the fact of the queen's public endorsement of the cause of animal protection, a degree of "fashionableness" it had not been able to achieve on its own.

From the outset the RSPCA was conservative in every sense of the word. It sought to disassociate itself from "extremists," including Lewis Gompertz, author of Moral Inquiries on the Situation of Man and Brutes (1824), who, in addition to refusing to ride in horsedrawn carriages, refused on principle to eat other animals. In addition, the RSPCA displayed a marked tendency to oppose cruelty when it was attributable to the working-class while turning a blind eye to the finer cruelties of the affluent. This double standard was too much for Mill's sense of social justice; writing to the secretary on 26 July 1868 , he divested himself from the RSPCA for as long as "it is thought necessary or advisable to limit the Society's operations to the offences committed by the uninfluential classes of society." Evidently the Society never changed, since Mill never rejoined. As Ryder explains, in what many will find to be the most interesting, instructive part of his book, these divisive conflicts among the very people who sought to help nonhuman animals were to increase, both in number and intensity, during the next hundred years, a point I return to below.

Even while conflicts increased and intensified, Ryder believes that the cause of animal protection made progress in Britain during the nineteenth century. It would be tempting to attribute this to the growing willingness to accept Darwin's theory of evolution. Ryder disagrees. Today, it is true, appeals to Darwin are commonplace. If humans and other animals resemble one another in morally relevant ways, then it would be rationally indefensible to treat them in radically different ways. People appeal to Darwin to replace the "if" with a "because": Because (as Darwin has shown) humans and other animals resemble one another in morally relevant ways, it is rationally indefensible to treat them in radically different ways.

According to Ryder, the situation was quite different in Darwin's day. The principle advocates of his theory back then were his scientific peers, including the growing army of vivisectors, and although Darwin himself abhorred vivisection and abandoned a possible career in medicine because he could not bear to vivisect, animal protectionists, in a classic case of confusing the message with the messengers, were among the theory's most vocal critics. Precisely because vivisectors championed the theory of evolution, those who opposed vivisection opposed the theory. Perhaps there is a lesson to be learned here, and in one sense, of course, there is: We ought not to confuse the message with the messenger. That's the easy part. The hard part is to carry out this wise injunction in practice-as if, for example, those who oppose vivisection must oppose all biotechnology, because vivisectors support it.

Why, then, in view of the relative impotence of Darwin's theory to account for the progress in animal protection, did the cause of animals make progress in the nineteenth century? Ryder's explanation seems to be sociopolitical. That Queen Victoria would lend her royal name to a cause lent that cause a certain credibility, to be sure, and the discovery of anaesthetic also played a role. But far and away the most important changes concerned, first, the emergence of a growing middle class, and, second, the blessing of a comparatively long period of national peace. Ryder writes:

As for the industrial revolution, it increased affluence and created a large middle class [and] liberated some minds to ponder the plight of 
nonhumans...[a] tendency [that] was augmented by the fact that Britain in the nineteenth century enjoyed an almost unprecedented period of peace which stretched, interrupted only by the Crimean and colonial campaigns (which never, of course, produced any fear of invasion) from 1815 till the end of the century. After the 1830s the middle and upper middie class felt relatively safe; few external threats distracted them from considering the suffering of others (p. 165).

For a variety of reasons, then, these "others" in time came to be seen to include other (nonhuman) animals. Again, I return to this finding of Ryder's below.

Earlier I mentioned the theme of division and conflict, as it emerges in the latter part of the nineteenth century in Britain. If there is some one person more responsible than any other for this, it may be Frances Power Cobbe, whom Ryder characterizes as "the most doughty and effective anti-vivisectionist of the nineteenth century" (p. 108). Cobbe's life has been well told by John Vyvyan in his In Pity and in Anger, first published in 1969 and reprinted in 1987 (Micah Press). Ryder's account lacks some of the verve and humor of Vyvyan's, but the main outlines bring this remarkable woman alive.

Dissatisfied with the conservative, incremental, regulatory approach to vivisection favored by the RSPCA, Cobbe decided to pursue an abolitionist agenda. This led her to form, in November, 1875, the Victoria Street Society, later to be renamed the National Anti-Vivisection Society (NAVS), which Cobbe ably led for more than two decades, only to find herself and her allies out-voted in the NAVS elections of 1898 , whereupon she formed the British Union Against Vivisection (BUAV).

Cobbe did not carry her opposition to vivisection to the dinner table. Like Gompertz before her, Anna Kingsford thought a consistent anti-vivisectionism included vegetarianism, and like her conservative opponents in the RSPCA, Cobbe did not. And so it was that these two powerful, visionary and magnetic women, each committed in her way to the cause of animal protection, had an association better known for its antipathy than its warmth.

Kingsford and Cobbe's relationship is a microcosm of the macrocosmic patterns of conflict that have characterized not only the British but also the American "animal movement" during the last hundred years. There is, first, the all too common conflict between strong personalities, especially when those who clash, whether for reasons of temperament or philosophy, all want to lead. Second, there are those conflicts that arise as a result of alternative conceptions of the goals of animal protection. Is it only some research involving nonhuman animals that should be stopped, or all of it? Should we work to get these animals off people's plates, or just out of scientists' cages? As we see, the currently fashionable distinction between advocates of "animal welfare" and partisans of "animal rights" was foreshadowed in a previous age, as was the divisiveness this distinction can help create and sustain.

Moreover, even among those who share the same goals, and even assuming they are not divided by reasons of personality, the possibility of irreconcilable differences cannot be ruled out. For there remains the question of the means one may prudently or morally use in pursuit of these goals. Should we accept an incrementalist, one-step-at-a-time approach to the abolition of "animal model" research, for example, or would acceptance of this approach have the paradoxical consequence of prolonging the very practice one opposes? And, again, how far may one go in pursuit of one's goals? May the law be broken? Is violence ever justified? Lewis Gompertz experienced this kind of conflict first-hand when he was roundly criticized for using "informers" to help him prosecute those who broke the law, just as today those abolitionists who sanction violence and law-breaking must confront the condemnation of their more Gandhian peers.

What is to be done about such conflicts? How, if at all, might people who want to help nonhuman animals begin to look past their differences and embrace their commonalities? Obviously, there is no easy answer. Some differences are real, after all. Still, there may be ways of minimizing them, even when they exist, and it may be possible for philosophers to find the way. Ryder presents one such opportunity for his philosopher-peers.

Among the contemporary controversies Ryder discusses, one concerns the "What-language-shouldwe-use?" question. Should we say that animals "have rights," or should we abjure this way of speaking? Ryder sides with those who would abjure speaking of "animal rights" because, he says, "it seems to me to be synthetic and unconvincing-whether applied in the human case or otherwise" (p. 328). What it means to say that this way of speaking is "synthetic" is never 
explained, whereas what it means to say that it is "unconvincing," so far as Ryder is concerned, seems reasonably clear: Ryder simply is not convinced that humans or other animals have rights. Very well. But why, precisely? Merely to be told by Ryder that he regards this way of speaking as "synthetic" is not enough. Is there any other reason? Perhaps. The third of the following points may be that reason.

It is to be noted, first, that by disavowing the vocabulary of "rights," Ryder does not see himself as having to embrace utilitarianism. For Ryder does not think that we can, nor therefore that we should, aggregate gains and losses across individuals; that is, Ryder does not side with utilitarians when they imply that harming one individual can be justified on the grounds that other individuals benefit. Here, then, he honors the spirit, even as he departs from the letter, of "animal rights."

Second, Ryder distances himself from animal rightists, and draws nearer to traditional utilitarians, because he thinks that preventable suffering is the core concept in ethics; animal rightists, by contrast, are thought by Ryder to believe that something other than suffering (for example, being used merely as a means, or as a tool, or as a resource) is the core concept. Ryder, it seems to me, does not do justice to the breadth and depth of the philosophical debate in these quarters (see, especially, pp. 325-329), which makes his embrace of the utilitarian view, as he understands it, even in the limited way in which he embraces it, seem possibly impetuous.

But, third, quite apart from any conceptual or moral questions that might be pressed, there is a way to understand why an Englishman like Ryder might find talk of animal or human rights "synthetic." For there is no tradition of individual rights in British moral and legal theory or practice, comparable to the one we find in America. Here (in America, that is) our moral vocabulary and thought, from the founding of this nation onward, have been molded around the idea of individual rights; in other places, and in other times, the situation has been markedly different. Thus may it seem, and understandably so, that the emphasis on the rights of the individual could seem "synthetic" to someone from a tradition in which this idea has played a less central role.

Is there anything that might be learned from this? Possibly. If there is, I think it is this: We need to learn to accept the inevitability of the plurality of ways of thinking and talking morally. For many people, the locus of ethics is individual responsibility; for others, caring; for still others, the general welfare; and for still others, virtuous character or individual rights. Philosophically, there may be a correct way of grounding the moral institution of life. This remains a live philosophical option. But from a practical point of view, we may do better to learn to speak in the tongues of the many, foreswearing any presumption that we personally are privileged to speak in the language of the wise few. In other words, we may do well to recognize which ways of talking are likely to seem "synthetic" to a given audience, to explore, both thoughtfully and fairly, just how far a given way of thinking and talking might take us when it comes to animal protection, and to learn, therefore, how extensive is the common ground which partisans of alternative views might actually share. Philosophers, in short, might teach by example when it comes to minimizing the sense of conflict and division that has characterized the efforts of people who want to make this world better for the nonhuman animals with whom we share it.

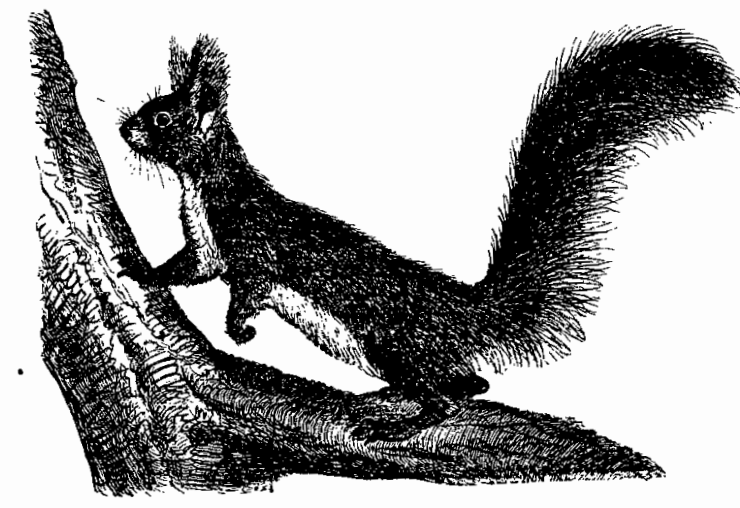

About the future, Ryder is optimistic. "It may take thirty or forty years for a movement such as ours to turn the great ships of commerce and custom, "he writes (pp. 331-331), but, he implies, turn them we will-in thirty or forty years. This may prove to be overly optimistic on Ryder's part even granting him, what is debatable, his beliefs that compassion and squeamishness are "innate" human capacities. Moreover, Ryder's optimism about the future does not seem to square with his explanation about the past. Recall the earlier discussion of why animal protection efforts gained momentum in Britain during the nineteenth century; 
the major causes, it seems, were protracted peace and material prosperity.

Peace we thought was at hand when, to everyone's relief, the cold war came to an apparent end and (or so it was thought) we entered a "new world order." And prosperity? Well, once the need to arm ourselves to the teeth evaporated, the money left over, the much ballyhooed "peace dividend," could be used to educate the young, house the poor, tend the elderly, and generally to share an abundant material prosperity to more and more people.

Times change. Even as I write this, the United States and Iraq remain at war, and the "peace dividend" has found its way into arming and supporting upwards of 500,000 combat-ready soldiers. So much for the "peace dividend." And so much for helping others prosper materially. The plain fact is, the poor are getting poorer, those who need housing most are getting less, the elderly are being warehoused in institutions of despair, and so on. If, then, Ryder is right in believing that peace and prosperity are needed if animal protection efforts are to meet with success, the present looks more like the worst than the best of times for the animals.

This should hardly be surprising. Making the world better for nonhuman animals is not something that can be achieved independently of making the world better for human beings. The slogan, "Animal liberation is human liberation," is more than a slogan. Genuine advances in the justice and quality of life made available to the one are inseparable from similar advances made for the other. Things do change in the sense that the identities of the victims of injustice, whether human or otherwise, differ over time; but so long as injustice rules, whether the victims are humans or other animals, things stay the same.

This is why animal advocates who restrict their time and energy to animal liberation might pause to ask, not whether our brothers and sisters in fur and feathers and fins deserve justice (for they do) but whether they have any realistic chance of obtaining it if we are blind to the injustice suffered by our brothers and sisters in human form. This is not to say that we should abandon the other animals and give all our time and energy to righting human injustices. This is not to say that at all. It is only to say that we need to consider the promise and power of a more complete activism. If there is one point in Ryder's book about animal advocates of the past that is of particular relevance to animal advocates of the present, this is it.

\section{Response to Regan: Sentientism}

\section{Richard D. Ryder}

I am flattered by Tom Regan's very kind and interesting review of my book Animal Revolution: Changing Attitudes Towards Speciesism, not least because of his own unparalleled contribution to the cause. I hope my work is more than just a history of the animal movement; I have tried to introduce some new psychological, philosophical, and political ideas on the way.

Regan draws attention to my view that Darwinism did not contribute much to the nineteenth century animal campaigns. One reason for this was that animal welfare had already become, by the 1860 's, a part of the British orthodox establishment. Darwin was, in effect, firmly kidnapped by scientific provivisectors like Huxley who challenged that orthodoxy. In consequence animal welfarists saw Darwin as their enemy rather than friend.

It was this paradox that struck me as an undergraduate at Cambridge in the early 1960's. Why was it that the scientists who happily experimented on animals were the same people who based their philosophies upon Darwinian evolution? Experimentation seemed to me to have become the blood ritual of an alternative and cannibalistic religion; it preached kinship and yet urged the ruthless exploitation of kin. This apparent inconsistency rankled inside me until my indignation erupted in newspaper letters written in Oxford in 1969 in which I spelt out what I considered to be the moral implications of Darwin's message. Ironically, after some years of campaigning on this Darwinian basis, I now consider that morality is better based upon sentiency than upon evolutionary kinship. Hence my promotion of what I call sentientism - the moral primacy of the individual's capacity to feel pain or distress regardless as to whether these states are experienced by a human, a rat, an alien,

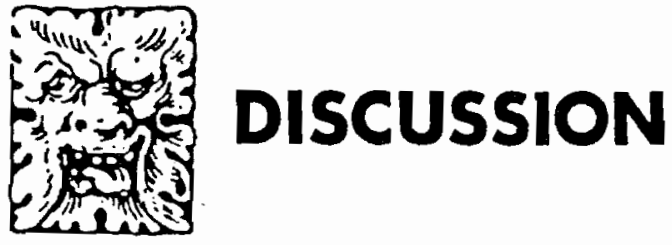

